\title{
ЭВОЛЮЦИЯ ЭНЕРГЕТИКИ: ИССЛЕДОВАНИЕ ВЛИЯНИЕ РАЗВИТИЯ НВИЭ НА ТРАДИЦИОННУЮ ЭНЕРГЕТИКУ НА ПРИМЕРЕ ОСТРОВА САХАЛИН
}

\author{
(C) 2021 Красников Владислав Игоревич \\ Высшая школа высоковольтной энергетики \\ Санкт-Петербургский политехнический университет Петра Великого, Россия, Санкт-Петербург \\ E-mail: krasnikov.vi@edu.spbstu.ru
}

(c) 2021 Щеников Егор Михайлович

Высшая школа высоковольтной энергетики

Санкт-Петербургский политехнический университет Петра Великого, Россия, Санкт-Петербург

E-mail: tshenikov.em@edu.spbstu.ru

(c) 2021 Дегтярев Иван Александрович

Высшая школа высоковольтной энергетики

Санкт-Петербургский политехнический университет Петра Великого, Россия, Санкт-Петербург

E-mail: degtyarev.ia@edu.spbstu.ru

(c) 2021 Богданова Марина Олеговна

Высшая школа высоковольтной энергетики

Санкт-Петербургский политехнический университет Петра Великого, Россия, Санкт-Петербург

E-mail: bogdanova.mo@edu.spbstu.ru

(c) 2021 Новикова Ольга Валентиновна

кандидат экономических наук, Высшая инженерно-экономическая школа

Санкт-Петербургский политехнический университет Петра Великого, Россия, Санкт-Петербург

E-mail: novikova-olga1970@yandex.ru

Авторы исследуют реальные перспективы эволюции энергетики, с учетом общемирового тренда большого влияния ВИЭ для России путем оценки технико-экономических последствий в каждом конкретном энергорайоне ввиду неравномерности потенциала реализации различных технологий и формирования неоднозначных проектных решений в электроэнергетических системах. Представлены расчеты технико-экономических последствий реализации ветропарка, обусловленные особенностью энергобаланса острова Сахалин, структурой его экономики и экологических показателей загрязнения воздуха. Оценены показатели экономической эффективности проекта. Сделаны выводы о дополнительных коммерческих эффектах для традиционной энергетики при вводе ВЭС.

Ключевые слова: эволюция энергетики, нетрадиционные возобновляемые источники энергии, валовый региональный продукт, выбросы загрязняющих веществ.

Введение. Исторически сложившиеся технологические трансформации энергетики предполагают глобальный переход в мире на использование новых видов топливных ресурсов или, как характеризуется четвертый энергетический переход, на глобальное использование возобновляемых источников энергии. Однако, энергосистемы мира демонстрирует не равномерность этого перехода. С каждым годом роль нетрадиционных возобновляемых источников энергии (НВИЭ) в энергетике России становится все ощутимее: увеличивается установленная мощность, расширяется география применения НВИЭ, ве- дутся разработки по модернизации технологий получения электроэнергии из возобновляемых источников. Их практическое внедрение происходит в мире разными темпами. А для России, имеющей территорию с существенно различающимся потенциалом ВИЭ [1] и неравномерным распределением центров потребления и центров добычи традиционных энергоресурсов ключевое значение имеет общегосударственная или региональная энергетическая политика $[2$, $3,4,5,6]$. Для исследования реальных перспектив эволюции энергетики, которая предполагает большое влияние ВИЭ для России становится 
важным прогнозирование и оценка техникоэкономических последствий в каждом конкретном энергорайоне [7].

Актуальность. Сахалинская область входит в состав наиболее перспективных для развития НВИЭ регионов страны [8]. Внедрение электростанций на возобновляемых источниках позволит повысить энергоэффективность района, снизить объемы выбросов вредных газов, а также снизить зависимость от дизельного топлива. Особенности экономики региона отражены в ВРП, где видно, что добыча и поставка угля на экспорт является существенной статьей дохода (57\%) [9].

Однако стоит отметить некую противоречивость в актуальности установки ВИЭ в районе города Углегорск. В Центральном районе существует избыток мощности [10], и даже при запланированной модернизации достаточно энергоёмких объектов угледобычи и введения новых электропотребляющих устройств [10] избыток мощности сохранится сверх нормативного. Предположение о существенной экологизации энергетики, требует дополнительного исследования. При изменении источника электропитания объектов угледобывающей промышленности на ветроэнергетическую станцию (ВЭС), экологические показатели в регионе существенно не изменяться, так как в основном качество воздуха страдает как раз в процессе добычи и транспортировки угля. Электроснабжение конвейера от ВЭС исключает выбросы СО2 при сравнении этой величины с выбросами от альтернативного дизельгенератора. Однако, мы уже определили наличие существенного запаса по мощности от действующих генерирующих объектов. Объективно, причина установки ВЭС в Углегорском районе может состоять в поддержание тренда экологизации генерации и приоритете выбора НВИЭ в качестве мощного источника электроэнергии.

Целью исследования стала оценка перспектив внедрения крупных НВИЭ в энергосеть острова Сахалин. Для этого рассмотрим на конкретном примере экономическую обоснованность создания ВЭС в Углегорском районе и проведем оценку рисков внедрения ВЭС на Сахалине. Основными методами исследования, применяемыми в данной работе, являются анализ статистики, оценка показателей экономической эффективности, PESTEL- анализ, синтез и индукция.

В целом, Сахалинская область является при- влекательной для строительства ВЭС, так как регион обладает внушительным ветровым потенциалом (Рис. 1.). Это заметили и крупные компании, что привело к тому, что начали прорабатывать проекты ветропарка на острове.

Первым примером стали 2 ВЭУ суммарной мощностью 0.45 МВт в селе Новиково, построенные в 2015 году [11]. Затем, в селе Головино с аналогичной мощностью. В 2021 году появилась новость о том, что будет реализован проект ветропарка мощностью уже 67.2 МВт [12]. Назначение новой ВЭС - снабжение промышленных потребителей “Восточной горнорудной компании” в городе Углегорск.

Планируется, что запуск данной ВЭС улучшит экологическую ситуацию на островах. По данным национального экологического рейтинга Сахалинская область занимает 63 место из 85 субъектов РФ [13]. На Рис. 2 представлены выбросы загрязняющих веществ от отдельных групп источников загрязнения. Выбросы от стационарных источников в 2019 году, по данным Дальневосточного межрегионального управления Росприроднадзора, составили 56,709 тыс. тонн, в том числе: твердых веществ - 11,339 тыс. тонн, газообразных и жидких - 45,37 тыс. тонн. Выбросы от передвижных источников в 2019 году по данным Единой межведомственной информационно-статистической системы Российской Федерации составили 39,21 тыс. тонн.

В Сахалинской области приоритетными загрязнителями атмосферного воздуха являются диоксид азота, сажа, диоксид серы, оксид углерода, взвешенные вещества, бензапирен, бензол, сероводород. В 2019 году произошло снижение показателя доли проб атмосферного воздуха, не соответствующих гигиеническим нормативам по Сахалинской области по сравнению с предыдущим годом на 34,6\% [14].

Полевые и лабораторные исследования качества атмосферного воздуха, проведенные в 2019 году в двух населенных пунктах Углегорского района (г. Углегорск, г. Шахтерск) и на двух угольных разрезах, позволили выявить следующее: в г. Углегорск атмосферный воздух можно отнести к низкой степени загрязнения, в г. Шахтерск - к повышенной степени загрязнения. Среднегодовой комплексный индекс загрязнения атмосферы (ИЗА5) в 2019 году составил в г. Углегорске 5,3, в г. Шахтерске - 6,6 [14].

С точки зрения электроснабжения, Углегорск попадает в зону деятельности ПАО Саха- 


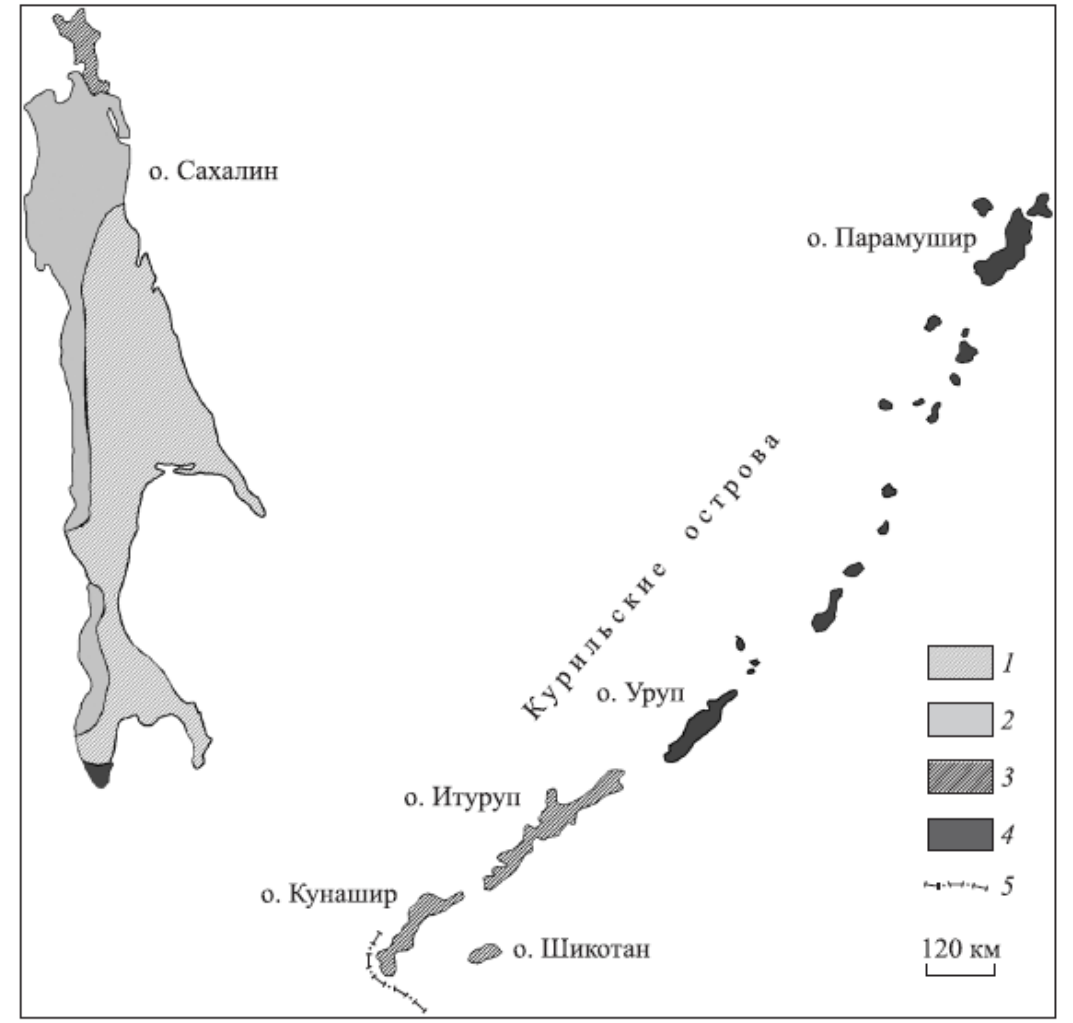

Распределение среднегодовой скорости ветра в зонах 1-4 на высоте 9-12 м по данным метеостанций Сахалинской области.

Среднегодовая скорость ветра, м/с: $1-2-5 ; 2-4-6 ; 3-6-8 ; 4-$ более 8.5 - государственная граница.

Puc. 1. Карта среднегодовой скорости ветра на территории России

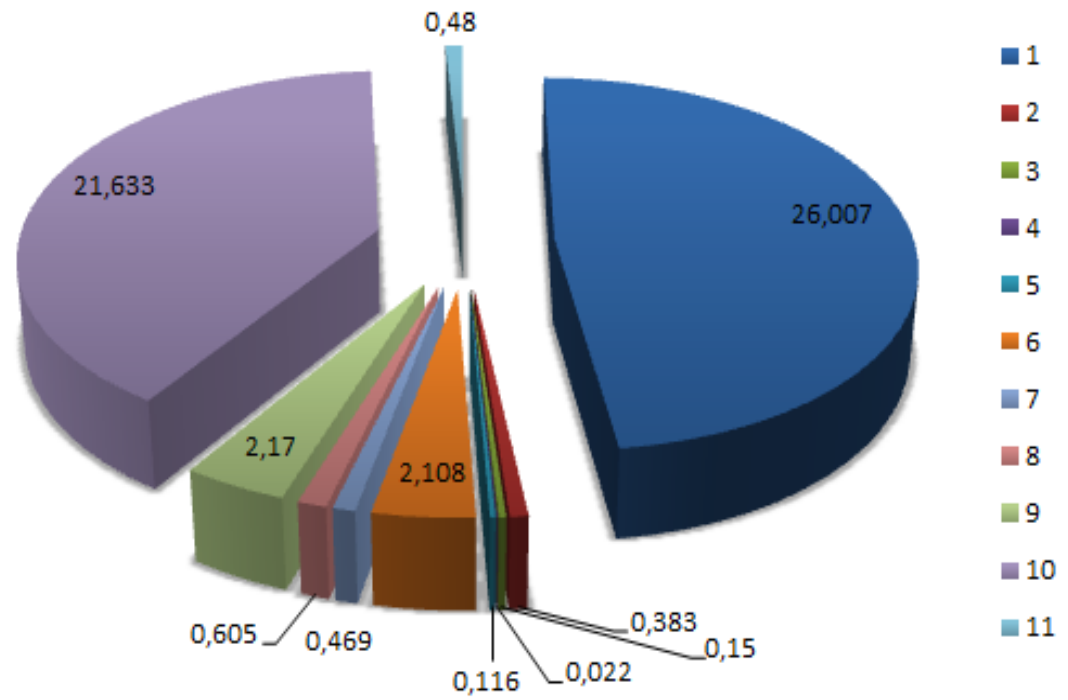

1- Добыча полезных ископаемых; 2 - Сельское хозяйство, охота и лесное хозяйство; 3 - Прочие виды экономической деятельности; 4 - Деятельность профессиональная, научная и техническая; 5 - Деятельность по операциям с недвижимым имуществом; 6 - Транспортировка и хранение; 7- Торговля оптовая и розничная; ремонт автотранспортных средств и мотоциклов; 8 - Строительство; 9 - Водоснабжение; водоотведение, организация сбора и утилизации отходов; 10 - Обеспечение электрической энергией, газом и паром; кондиционирование воздуха; 11 - Обрабатывающие производства.

Рис. 2. Выбросы загрязняющих веществ от отдельных групп источников загрязнения по видам экономической деятельности, тыс. тонн 
линэнерго в состав Центрального энергоузла, который характеризуется двумя аспектами: сверхнормативный запас мощности и тренд на увеличение спроса. Динамика представлена графиком на рис. 3 [15].

Южно-Сахалинская ТЭЦ-1 и Сахалинская ГРЭС-2 маломаневренные, что может вызвать осложнения в регулировании перетоков мощности при совместной работе с ВЭС. Однако современные устройства контроля и учёта потребления электроэнергии (умные счётчики) и цифровые методы управления энергосетями (цифровая РЭС и цифровая подстанция) вполне могут поспособствовать чёткому и равномерному распределению мощности потребляемой энергосистемой в районе Углегорска, увеличив вероятность внедрения НВИЭ.

Ногликская ГЭС является маневренной, но её не учитываем в связи с небольшой установленной мощностью. Перечисленные выше электростанции позволяют резервировать мощность (см. Таблицу 1) [15].

Оценим выработку и величину потерь в сетях при введении ветропарка в Центральном энергоузле. Экспертами компании «Ветропарк» была определена возможность достижения коэффициента использования установленной мощности: 35\% и выше [16]. Однако, согласно данным Системного оператора, максимальное значение КИУМ (ОЭС Средней Волги) равняется всего лишь 28.43\% [17]. Стоит отметить, что приведенное выше значение является среднегодовым, так как в некоторых кварталах коэффициент становится равным 37.35\% [18]. Учтем, что проектируемая ВЭС будет работать на добычу, а не в сети, то есть не будет необходимости экстренно отключаться для обеспечения оптимальной работы соседних станций, и примем КИУМ равный 30\%. Тогда вырабатываемая электроэнергия за год будет равна:

$$
\mathrm{W}=8760 \cdot 67.2 \cdot 0.3=176602 \approx 177 \text { млн. кВт.ч }
$$

Потери в сетях составляют около 11\% (в год 19.47 млн. кВт·ч).

Также важными факторами являются среднесуточная скорость ветра и его повторяемость. Среднесуточная скорость ветра в Углегорске определена в среднем за год и составляет 5.2 м/с [19]. Данные по вероятности скоростей ветра приведены в Таблице 2 .

Для расчета показателей экономической эффективности была проведена оценка себестоимости с учетом капитальных затрат (проект рассматривается на период с 2022 по 2035 год). Полученные данные сведены в таблицу 3.

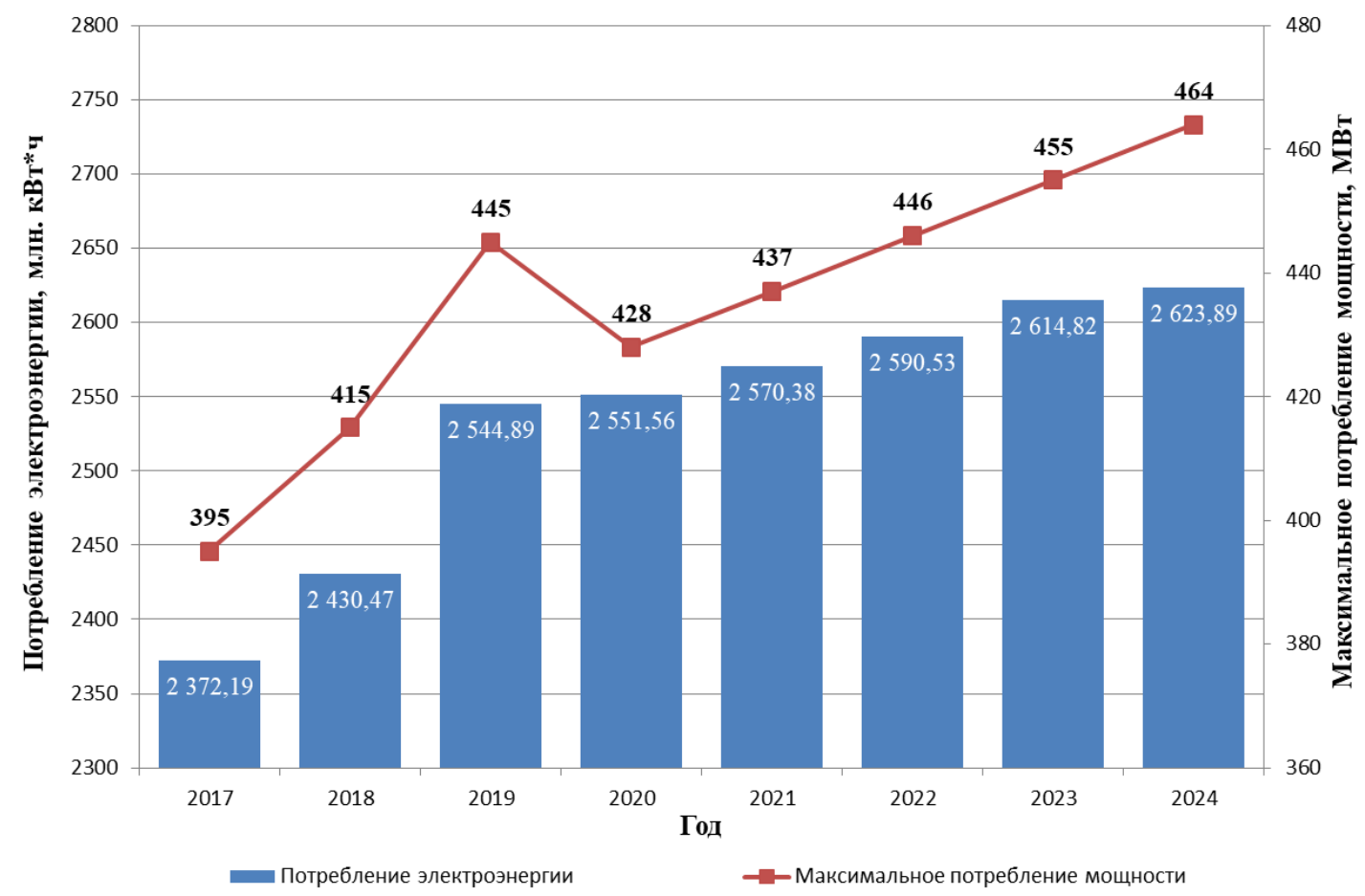

Рuс. 3. Графики максимального потребления электроэнергии и мощности Центрального энергорайона 
Таблица 1. Баланс мощности Центрального энергорайона, МВт

\begin{tabular}{|l|c|c|l|}
\hline \multicolumn{1}{|c|}{ Наименование показателей } & 2020 г. & $\begin{array}{c}\text { Часть в произ- } \\
\text { водстве э/э, \% }\end{array}$ & Вид топлива \\
\hline Суммарная установленная мощность, в т.ч. & 634,74 & 100 & \\
\hline «Южно-Сахалинская ТЭЦ-1» & 455,24 & 78,3 & $\begin{array}{l}\text { Природный газ (основное) } \\
\text { Бурый уголь, мазут (резервное) }\end{array}$ \\
\hline «Сахалинская ГРЭС-2» & 120 & 13,9 & Бурый уголь, мазут \\
\hline «НГС» & 48 & 7,02 & Природный газ \\
\hline Блок-станции, в т.ч. & 11,5 & & \\
\hline «Томаринская ТЭЦ» & 6,5 & 0,5 & Уголь \\
\hline «Хлмская ТЭЦ» & 5 & 0,1 & Уголь, мазут \\
\hline Максимум потребления мощности & 428 & & \\
\hline Нормативный резерв мощности & 170 & & \\
\hline $\begin{array}{l}\text { Резерв мощности в \% от максимума потре- } \\
\text { бления }\end{array}$ & 39,72 & & \\
\hline Итого потребность в мощности & 598 & & \\
\hline $\begin{array}{l}\text { Дефицит (-), избыток (+) располагаемой } \\
\text { мощности }\end{array}$ & 33,74 & & \\
\hline
\end{tabular}

Таблица 2. Вероятность возникновения потоков различных скоростей

\begin{tabular}{|c|c|c|c|c|c|c|c|c|c|}
\hline Вероятность,\% & 19,4 & 17,2 & 16,3 & 15,4 & 13,2 & 11,9 & 3,1 & 1,8 & 1,8 \\
\hline Скорость ветра, м/с & $3,4-5,4$ & $5,5-7,9$ & $0,3-1,5$ & $1,6-3,3$ & $0-0,2$ & $8-10,7$ & $\begin{array}{c}10,8- \\
13,8\end{array}$ & $\begin{array}{c}13,9- \\
17,1\end{array}$ & $\begin{array}{c}17,2- \\
20,7\end{array}$ \\
\hline
\end{tabular}

Таблица 3. Экономические показатели проекта

\begin{tabular}{|c|c|}
\hline Показатель & Величина \\
\hline Установленная мощность & 67.2 МВт \\
\hline САРЕХ & 7196 млн. руб \\
\hline OPEX & 1707 млн. руб \\
\hline DPBP & 11 лет \\
\hline NPV & 1834.6 млн. руб \\
\hline IRR & $10.9 \%$ \\
\hline PI & 1.18 \\
\hline Бюджетный эффект & 2561 млн. руб \\
\hline
\end{tabular}

Для наглядности оценим удельную величину капитальных затрат:

$$
C A P E X_{\text {уд }}=\frac{7196000000}{67.2 \cdot 1000}=107 \text { тыс.руб/кВт }
$$

Согласно данным Минэнерго [20], предельные капитальные затраты на возведение 1 кВт мощности ВЭС в 2020 году составили 109451 руб/ кВт, а средние - 65000 руб/кВт. Таким образом, полученное значение находится в диапазоне, ближе к верхней границе.
При оценке операционных затрат за основу были взяты данные из [21]:

$$
\mathrm{C}=\frac{1706925340}{67.2 \cdot 1000 \cdot 13}=2 \text { тыс.руб/кВт }
$$

Согласно информации Российской Ассоциации Ветроиндустрии (РАВИ) операционные затраты могут варьироваться от 1500 до 3000 руб/ кВт [22].

Риск изменения чистого дисконтированного дохода с течением времени рассчитан для трех 
ставок дисконтирования (Рис. 4).

При определении выручки были использованы реальные величины тарифов на электроэнергию и мощность, причем была рассмотрена динамика их изменения во времени, что позволило спрогнозировать их величину до 2035 года.

Авторами определена ожидаемая динамика выручки от продажи электроэнергии и мощности ВЭС за рассматриваемый период. Соответствующий график приведен на рис. 5.
На рис. 5 синим цветом выделена выручка от продажи мощности, а красным - от продажи электроэнергии.

С целью определения основных рисков, с которыми придется столкнуться при реализации проекта, был проведен PESTEL-анализ строительства ВЭС на Сахалине. Были также предложены меры по управлению данными рисками (см. Таблицу 4).

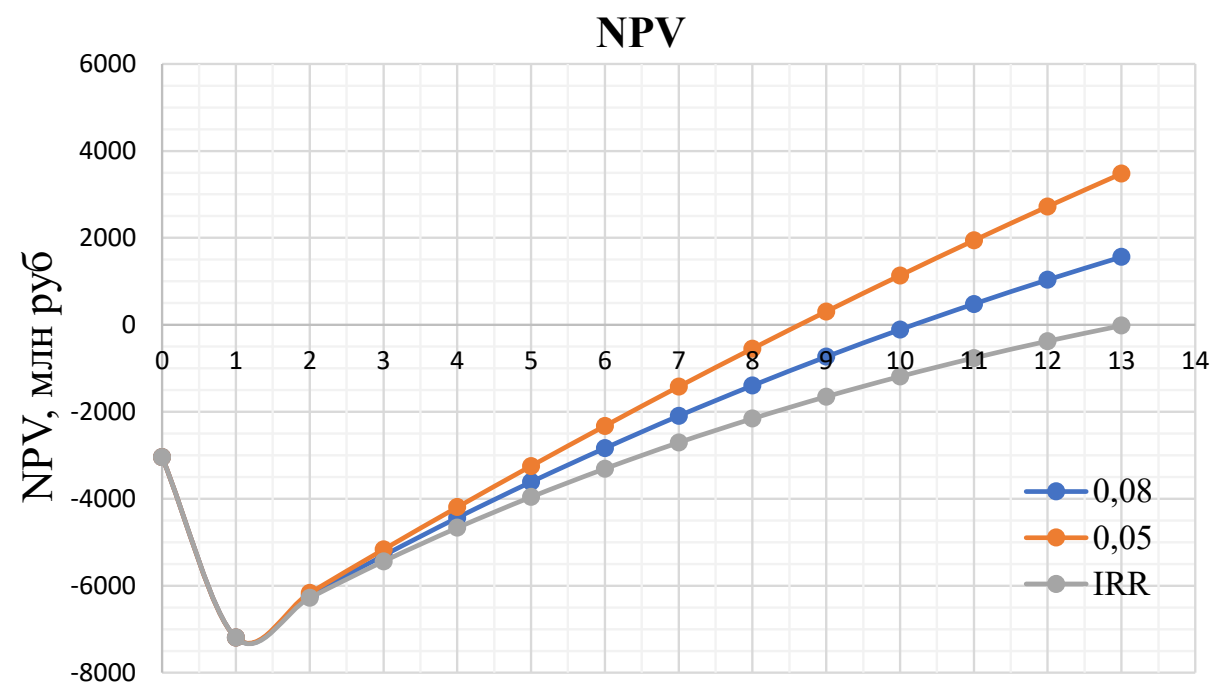

$\mathrm{n}$, год

Puc. 4. График NPV

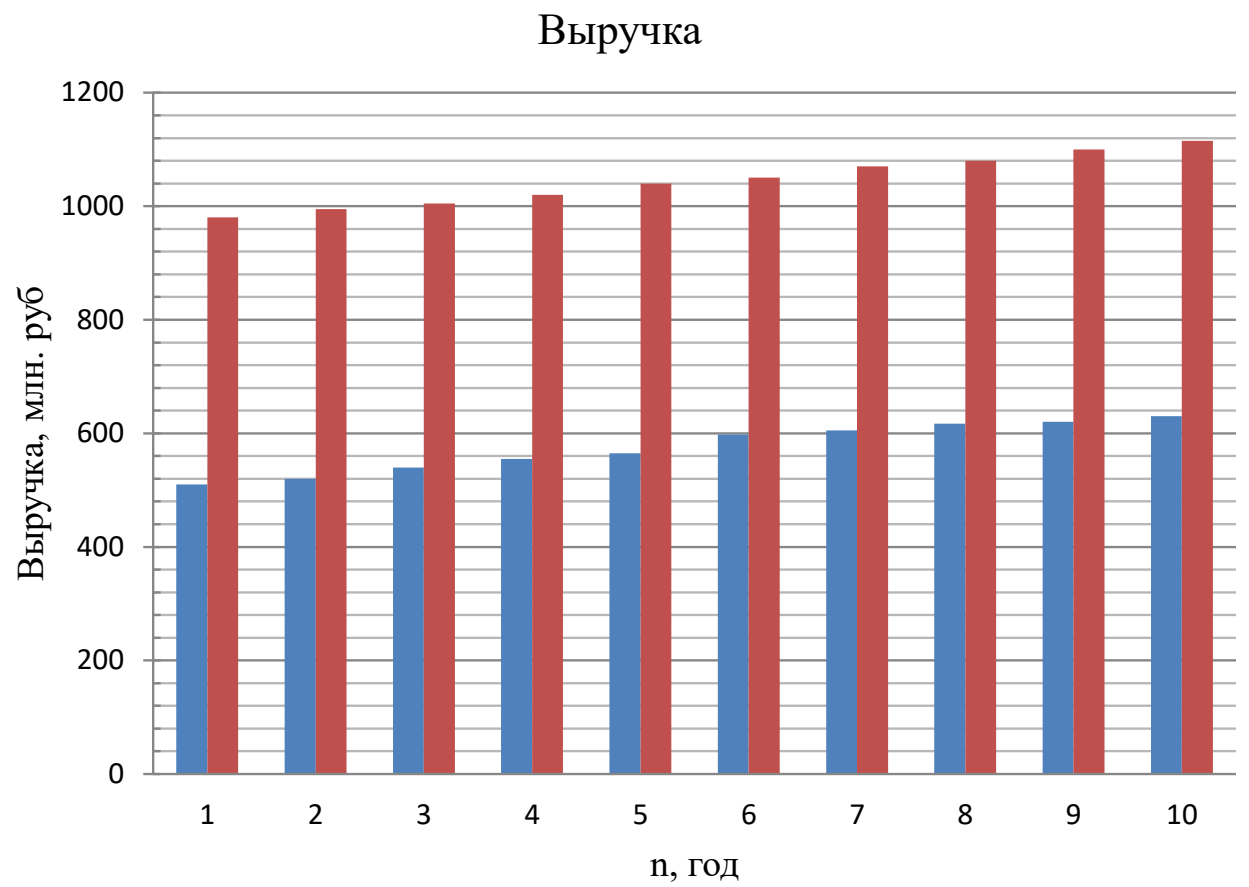

Puc. 5. Динамика выручки за 10 лет 
Таблица 4. PESTEL-анализ

\begin{tabular}{|c|c|}
\hline Риск & Управление риском \\
\hline \multicolumn{2}{|c|}{ Политические риски } \\
\hline $\begin{array}{l}\text { Потеря рынков сбыта угля, связанная с обострением } \\
\text { внешнеполитической обстановки }\end{array}$ & Принятие и учет при управлении проектом \\
\hline \multicolumn{2}{|c|}{ Экономические риски } \\
\hline $\begin{array}{l}\text { Увеличение сроков строительства, связанное с тяже- } \\
\text { лыми климатическими условиями }\end{array}$ & $\begin{array}{l}\text { Снижение - грамотное составление плана строи- } \\
\text { тельных работ, которое бы минимизировало влияние } \\
\text { погодных условий }\end{array}$ \\
\hline \multicolumn{2}{|c|}{ Социокультурные риски } \\
\hline $\begin{array}{l}\text { Снижение надежности электроснабжения потребите- } \\
\text { лей при выходе из строя оборудования, связанного с } \\
\text { неблагоприятными погодными условиями }\end{array}$ & $\begin{array}{l}\text { Снижение - применение методов прогнозирования } \\
\text { и непрерывного мониторинга состояния ветроуста- } \\
\text { новок, погодных условий }\end{array}$ \\
\hline \multicolumn{2}{|c|}{ Технологические риски } \\
\hline $\begin{array}{l}\text { Выход из строя оборудования, вызванный ускорен- } \\
\text { ным старением в тяжелых климатических условиях }\end{array}$ & Принятие и учет при управлении проектом \\
\hline $\begin{array}{l}\text { Запирание мощностей, вызванное наличием старых } \\
\text { и изношенных сетей }\end{array}$ & Принятие и учет при управлении проектом \\
\hline \multicolumn{2}{|c|}{ Экологические риски } \\
\hline $\begin{array}{l}\text { Изменение микроклимата, вызванное строитель- } \\
\text { ством крупного ветропарка }\end{array}$ & $\begin{array}{l}\text { Снижение - моделирование ВЭС, которое позволило } \\
\text { бы оценить негативное влияние на микроклимат }\end{array}$ \\
\hline \multicolumn{2}{|c|}{ Юридические риски } \\
\hline $\begin{array}{l}\text { Изменение требований программы ДПМ ВИЭ-2 или } \\
\text { их несоблюдения }\end{array}$ & Принятие и учет при управлении проектом \\
\hline
\end{tabular}

С учетом вышеизложенного, можно сделать вывод, что проект строительства ВЭС на Сахалине именно в указанном месте имеет ряд значительных рисков. К ним можно отнести существующий избыток мощностей энергорайона и большое число аварий, вызванных погодными условиями [3]. С другой стороны, несмотря на привлекательность использования ветрового ресурса острова Сахалин, существует ряд других, более перспективных для развития ветроэнергетики мест даже внутри острова [23]. Более того, ВЭС характеризуются меньшими сроками эксплуатации по сравнению со станциями на традиционных источниках энергии.

Одним из наиболее значимых драйверов, располагающих к строительству ВЭС на Сахалине, является наличие углеродного налога, которым облагается импортируемая в страны продукция, при производстве которой было выделено значительное количество парниковых газов [24]. Использование электроэнергии, произведенной на ветроустановках, позволит снизить их величину при экспорте угля. Это особенно важно вследствие того, что основная часть добытого угля поставляется в зарубежные страны, которые данную политику учитывают [25]: Китай, Южную Корею, страны Юго-Восточной Азии [3].
Экспертами обосновывается улучшение экологической обстановки в регионе, связанное с сокращением выбросов 176 тонн углекислого газа в год при реализации концепции “Зеленого углеродного кластера”, частью которого и является строительство данной ВЭС [26]. Однако это станет возможным, если существующие объекты генерации на традиционных ресурсах снизят свою нагрузку.

\section{Выводы}

В ходе исследования был сделан вывод о том, что установка ВЭС на острове Сахалин является технически и экономически реализуемым проектом. Было выявлено, что вероятность прямого положительного экологического эффекта реализация данного проекта не значительна, в связи с тем, что вывод из эксплуатации действующих ТЭЦ не произойдет. Внедрение ВЭС в условиях избытка мощности приведет к снижению КИУМ ТЭС. Можно сделать вывод, что осуществление данного проекта позволит получить России практический опыт в создании и эксплуатации источников ВИЭ и продемонстрировать свою приверженность к эволюции энергетики. Также реализация проекта повлияет на имидж компании по добыче угля, которая продемонстрирует экологические улучшения. 
Было выявлено что внедрение ВЭС в энергосистему является технически и экономически осуществимой задачей, однако имеется необходимость в модернизации методов управления и распределения энергии на Сахалине, для устойчивого контроля перетоков мощности в сети и во избежание нестабильности в системе выра- ботки и потребления энергии.

Ввиду отсутствия опыта реализации экологичных технологий добычи, транспортирования и использования угля, например в цикле Аллама [27], авторы считают целесообразным рассмотрение эволюции энергетики с учетом экономических и экологических интересов региона.

\section{Библиографический список}

1. Аналитический обзор. Потенциал возобновляемых источников энергии в России. Существующие технологии. [Электронный ресурс] URL: https://allbeton.ru/upload/iblock/d80/potencial-vozobnovlyaemih-istochnikovenergii-v-rossii-analiticheskiy-obzor.pdf (Дата обращения 26.06.2021)

2. Государственная политика в области развития возобновляемой энергетики. [Электронный ресурс] URL: https://cyberleninka.ru/article/n/gosudarstvennaya-politika-v-oblasti-razvitiya-vozobnovlyaemoy-energetiki/ viewer (Дата обращения 26.06.2021)

3. Стратегия социально-экономического развития сахалинской области на период до2035 года. [Электронный ресурс] URL: https://www.economy.gov.ru/material/file/97d67779605e3966c56c0cdf1a9d221d/SO.pdf (Дата обращения 26.06.2021)

4. Бугаева, Т.М. Развитие и реализация возобновляемой энергии в России: проблемы и перспективы / Т. М. Бугаева, А. С. Куропятник, В. В. Бразовская // Неделя науки СПбПУ: Материалы научной конференции с международным участием. Институт промышленного менеджмента, экономики и торговли. В 3-х частях, Санкт-Петербург, 18-23 ноября 2019 года.- Санкт-Петербург: Федеральное государственное автономное образовательное учреждение высшего образования «Санкт-Петербургский политехнический университет Петра Великого», 2019.- С. 154-157.

5. Юркова, А.Б. Оценка перспектив развития возобновляемой энергетики в Республике Крым / А.Б. Юркова, Т. М. Бугаева // Неделя науки СПбПУ: материалы научной конференции с международным участием, СанктПетербург, 14-19 ноября 2016 года / Санкт-Петербургский политехнический университет Петра Великого.- Санкт-Петербург: Федеральное государственное автономное образовательное учреждение высшего образования «Санкт-Петербургский политехнический университет Петра Великого», 2016. - С. 356-359.

6. Кичигин, О.Э. Институциональный аспект формирования стратегических ориентиров государственной энергетической политики на региональном уровне при реализации стратегии национальной экономической безопасности / О.Э.Кичигин, Д.Г. Родионов // Экономика и предпринимательство.- 2017. - № 102(87).- С. 394-399.

7. Дмитриев, Н. Д. Оптимизация управленческих процессов в электроэнергетике на основе математического моделирования / Н. Д.Дмитриев, Д.Г. Родионов, С. А. Жильцов // Kant. - 2021. - № 1(38). - С. 18-23. - DOI 10.24923/2222-243Х.2021-38.4.

8. Григорьев, И.В. Применение альтернативных источников энергии на территории Сахалинской области / И.В.Григорьев. // Молодой ученый. - 2018. - № 26 (212).- С. 40-42.- URL: https://moluch.ru/ archive/212/51777/ (дата обращения: 26.06.2021).

9. Губернатор и правительство сахалинской области. Официальный сайт [Электронный ресуpc] URL: https:// sakhalin.gov.ru/?id=410 (Дата обращения 26.06.2021)

10. Указ об утверждении Схемы и Программы развития электроэнергетики Сахалинской области на 2020-2024 годы. [Электронный ресурс] URL: http://docs.cntd.ru/document/570766695 (Дата обращения 26.06.2021)

11. ПАО “Передвижная энергетика". Официальный сайт. [Электронный ресуpc] URL: http://xn-7sbbfhcgaebgxg2a2bcytk6b4ppb.xn - p1ai/projects/veu-v-sele-novikovo/ (Дата обращения 26.06.2021)

12. Российское государственное информационное агентство ТАСС. Официальный сайт [Электронный ресурс] URL: https://tass.ru/ekonomika/10978695 (Дата обращения 26.06.2021)

13. Общероссийская общественная организация “Зеленый патруль”. Официальный сайт [Электронный ресурс] URL: https://greenpatrol.ru/ru/stranica-dlya-obshchego-reytinga/ekologicheskiy-reyting-subektov-rf?tid=426

14. Доклад о состоянии и об охране окружающей среды в Сахалинской области в 2019 году. Министерство экологии Сахалинской области. Официальный сайт [Электронный ресурс] URL: https://ecology.sakhalin.gov.ru/ grajdanin/doklad-ehcology/ (Дата обращения 26.06.2021)

15. Схема и программа развития электроэнергетики Сахалинской области. [Электронный ресурc] URL: https:// minenergo.sakhalin.gov.ru/site_get_file/1206/ (Дата обращения 26.06.2021) 
16. Российская ассоциация ветроиндустрии. Официальный сайт [Электронный ресурc] URL: https://rawi. ru/2021/04/zelenyiy-veter-sahalina/ (Дата обращения 26.06.2021)

17. Отчет о функционировании ЕЭС России в 2020 году. [Электронный ресурс] URL: https://www.so-ups.ru/ fileadmin/files/company/reports/disclosure/2021/ups_rep2020.pdf (Дата обращения 26.06.2021)

18. Анализ показателей балансов электрической энергии и мощности ЕЭС России. [Электронный ресурс] URL: https://www.so-ups.ru/fileadmin/files/company/reports/ups-review/2021/ups_balance_analysis_2021q1.pdf (Дата обращения 26.06.2021)

19. Портал Climate-Energy. Ru [Электронный ресурс] URL: https://climate-energy.ru/weather/spravochnik/wdsp/ climate_sprav-wdsp_3208802127.php (Дата обращения 10.07.2021)

20. Министерство энергетики Российской Федерации. Официальный сайт [Электронный pecypc] URL: https:// minenergo.gov.ru/node/489 (Дата обращения 26.06.2021)

21. Дегтярев, К.С. Экономика возобновляемой энергетики в мире и в России / К. С.Дегтярев. // Научный сотрудник МГУ имени М.В. Ломоносова. - 2017. - № 9 (189). - С. 80-90. - URL: https://www.c-o-k.ru/articles/ ekonomika-vozobnovlyaemoy-energetiki-v-mire-i-v-rossii (дата обращения: 26.06.2021).

22. ОБЗОР российского ветроэнергетического рынка за 2018 год. [Электронный ресурc] URL: https://rawi.ru/ wp-content/uploads/2019/03/rawi-report-2018-full.pdf (Дата обращения 26.06.2021)

23. Агентство нефтегазовой информации. Официальный сайт [Электронный ресурс] URL: https://www.angi.ru/ (Дата обращения 26.06.2021)

24. What's a carbon tax? [Электронный ресурс] URL: https://www.carbontax.org/whats-a-carbon-tax/ (Дата обращения 26.06.2021)

25. Международные подходы к углеродному ценообразованию. [Электронный ресурс] URL: https://www. economy.gov.ru/material/file/c13068c695b51eb60ba8cb2006dd81c1/13777562.pdf (Дата обращения 26.06.2021)

26. ООО «Восточная горнорудная компания». Официальный сайт [Электронный ресурc] URL: https://www. eastmining.ru/novosti/vostochnaia-gornorudnaia-kompaniia-predstavila-kontceptciiu-zelenogo-ugol-nogoklastera/ (Дата обращения 26.06.2021)

27. Инновационная теплоэлектростанция работает без выбросов CO2 [Электронный pecypc] URL: https:/ econet.ru/articles/155469-innovatsionnaya-teploelektrostantsiya-rabotaet-bez-vybrosov-co2 (Дата обращения 26.06.2021) 